\title{
Upaya Meningkatkan Kemampuan Mengenal Huruf Hijaiyah melalui Media Gambar
}

\author{
Adolf Bastian', Suharni ${ }^{1}{ }^{\bowtie}$ \\ Pendidikan Usia Dini, Universitas Lancang Kuning, Indonesia(1) \\ DOI: $10.31004 /$ obsesi.v6i3.1772
}

\begin{abstract}
Abstrak
Penelitian ini bertujuan untuk meningkatkan kemampuan mengenal huruf hijaiyah anak melalui media gambar. Penelitian ini merupakan Penelitian Tindakan Kelas yang dilaksanakan di kelas B PAUD Duta Raudha Center Riau, dengan jumlah subjek penelitian 19 anak. Instrumen yang digunakan adalah pedoman observasi. Berdasarkan hasil penelitian ini, kemampuan mengenal huruf hijaiyah anak dapat ditingkatkan dengan menggunakan media gambar. Hasil pada siklus I diketahui terdapat peningkatan kemampuan mengenal huruf hijaiyah dibandingkan dengan sebelum tindakan. Pada siklus II diperoleh persentase lebih besar dan berada pada kriteria Berkembang Sangat Baik, dimana telah mencapai indikator keberhasilan yang telah ditetapkan. dengan demikian dapat dikatakan bahwa kemampuan mengenal huruf hijaiyah anak kelas B PAUD Duta Raudha Center Riau dapat ditingkatkan melalui media gambar.
\end{abstract}

Kata Kunci: huruf hijaiyah; kemampuan mengenal huruf; media gambar.

\begin{abstract}
This study aims to improve the children's ability to recognize hijaiyah letters through image as media. This is a Classroom Action Research conducted in class B PAUD Duta Raudha Center Riau, with 19 children as the number of subjects. The instrument used is an observation sheet. Based on the results of this study, children's ability to recognize hijaiyah letters can be improved by using image media. The results in the first cycle showed that there was an increase in the ability to recognize hijaiyah letters compared to before the action. In the second cycle, a higher percentage was obtained and was in the Very Good Developing criteria, which had reached the predetermined success indicators. Thus, it can be said that the ability to recognize hijaiyah letters for grade B children at the Duta Raudha Center Riau PAUD can be improved through image as the media.
\end{abstract}

Keywords: ability to recognize letters; hijaiyah letters; image media.

Copyright (c) 2021 Adolf Bastian, Suharni

$\triangle$ Corresponding author :

Email Address : suharni@unilak.ac.id (Pekanbaru, Riau, Indonesia)

Received 25 March 2021, Accepted 2 September 2021, Published 9 September 2021 


\section{PENDAHULUAN}

Pendidikan Anak Usia Dini (PAUD) merupakan jalur pendidikan formal yang berbentuk Taman Kanak- Kanak (TK). R. Sari (2017) mengemukakan bahwa anak usia dini merupakan masa yang paling optimal untuk berkembang, pada masa ini anak mempunyai rasa ingin tahu yang besar dan melakukan apapun untuk memenuhi rasa ingin tahunya. Selain itu secara naluriah mereka bergerak, mereka akan menuju kemana saja sesuai dengan minat dan kemauannya. Menurut Vygotsky dalam Sumarni (2019) meyakini bahwa anak melalui bermain anak mendapatkan informasi yang baru atau keterampilan-keterampilannya yang baru, anak juga dapat memecahkan masalah yang kompleks. Melalui bermain anak dapat mengembangkan perkembangan kognitif, fisik, emosi, sosial anak dan di dalam perkembangan bahasa anak. Anak dapat langsung terlibat dalam permainan melalui alat atau media simbolnya atau lambangnya. Misalnya dengan menggunakan media gambar.

Media gambar dapat dimanfaatkan untuk optimalisasi berbagai kemampuan yang dimiliki oleh anak seperti; meningkatkan konsentrasi belajar anak (Khotimah et al., 2020), hasil belajar (Sa'diyah \& Zuhdi, 2014), kosa kata bahasa Arab (Nazarah, 2017), kemampuan mengenal warna (Gusmita, 2018) dan kemampuan lainnya. Disamping itu media gambar juga dapat dimanfaatkan sebagai sarana mitigasi bencana alam (Rahiem \& Widiastuti, 2020), siaga bencana banjir (Purwani et al., 2019), dan lain sebagainya.

Berdasarkan Observasi yang Peneliti lakukan pada anak usia dini kelompok B usia 5-6 tahun di PAUD Raudha Center Riau menemukan masalah mengenai kemampuan membaca huruf hijaiyah anak. Permasalahannya adalah tentang kemampuan mengenal huruf hijaiyah diantaranya anak bisa membaca huruf hijaiyah seperti : A ('), Ba (ب),Ta (ت), tsa (ث). Namun anak belum bisa membaca huruf hijaiyah yang selanjutnya seperti : ja (飞), ha (ح), kho $(\dot{\tau})$, dal (د), zal (ذ), ra ( د), zai (j), sin (س), syin (ش), shod (ص), dhod (ض), tho (ط), dhlo (ظ), ain (ع),

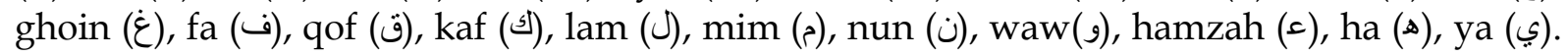
Oleh sebab itu dengan beberapa permasalahan yang dihadapi oleh anak seperti yang diatas, alternatif yang akan diberikan pada anak adalah mengenal lambang huruf hijaiyah melalui media gambar.maka dapat disimpulkan bahwa,anak hanya mampu menghafal bacaan hijaiyah, tetapi tidak mampu mengenal huruf hijaiyah. Adapun keunggulan dari media gambar ini antara lain adalah mudah di dapat dan mudah digunakan dan lebih realitis.

Hasil observasi menunjukkan bahwa selama mengajarkan huruf hijaiyah guru hanya sebentar mencontohkan cara membaca huruf hijaiyah. Maksudnya guru terlalu cepat dalam menjelaskan materi membaca huruf hijaiyah. Guru tergesa-gesa seolah-olah waktu tidak cukup untuk menyampaikan materi, Selain itu selama proses pembelajaran membaca huruf hijaiyah metode yang digunakan guru belum sesuai dengan karakteristik anak, dan guru hanya menggunakan media pembelajaran yang masih monoton dan kurang kreatif. Dalam hal ini, guru harus memiliki strategi berbeda dalam proses pembelajran. Strategi guru yang kreatif dan bervariasi tersebut harus dapat meningkatkan kreatifitas dan kemampuan anak (Makulua, 2015). Terutama kemampuan anak dalam mengenal huruf hijaiyah. Memvariasikan metode mengajar dengan media yang menarik dapat memberikan suasana belajar yang menyenangkan dan efektif. Media gambar merupakan salah satu media yang dapat digunakan oleh guru. Aprinawati (2017) menyatakan bahwa media gambar dapat digunakan untuk meningkatkan kemampuan anak usia dini. Mengenalkan lambang huruf hijaiyah dengan menggunakan media gambar memberikan solusi dalam memecahkan permasalahan di dalam kelas.

Suhati et al. (2014) menyatakan bahwa media gambar dapat meningkatkan kemampuan anak dalam mengenal huruf, $90 \%$ anak memberikan respon yang baik setelah melalui proses pembelajaran dengan menggunakan gambar sebagai media. Selain itu, kemampuan anak dalam mengenal huruf hijaiyah juga dapat ditingkatkan dengan menggunakan gambar. Hasan Syahrizal et al. (2021) menyatakan bahwa pengenalan huruf-huruf hijaiyah dengan menggunakan kartu bergambar dapat meningkatkan kemampuan anak dalam menyebutkan huruf hijaiyah, menunjukkan huruf hijaiyah, dan membedakan huruf hijaiyah. Penelitian di 
atas menyatakan bahwa gambar dapat membantu anak dalam mengenal huruf hijaiyah. Rini et al., (2014) menrapkan media bergambar pada anak SD kelas II yang masih dalam kategori anak usia dini (Unicef, 2017). Untuk itu peneliti berharap dengan pembelajaran huruf hijaiyah pada anak usia dini dapat dilaksanakan dengan menggunakan media gambar yang bervariasi atau bewarna-warni, menjadi media alternatif dalam proses pembelajaran, sehingga anak akan lebih tertarik untuk mempelajari huruf-huruf hijaiyah. Suasana pembelajaran dengan media bergambar sangat menyenangkan bagi anak dan seolah-olah menjadi kegiatan bermain, sehingga anak akan lebih mudah dalam menerima materi pembelajaran.

\section{METODOLOGI}

Metodologi penelitian ini adalah penelitian tindakan kelas (Inratyani, 2017) menyatakan bahwa penelitian tindakan kelas dapat memberikan solusi bagi permasalahan di kelas. Penelitian ini bertujuan untuk memberikan perbaikan pada kemampuan anak dalam mengenal huruf hijaiyah dengan menggunakan gambar sebagai media di PAUD Raudha Center Riau. Subjek penelitian ini terdiri dari 19 orang kelas B yang berumur 5-6 tahun. Pada proses penelitian ini, peneliti menerapkan gambar sebagai media yang dapat meningkatkan kemampuan anak dalam mengenal huruf Hijaiyah dalam 2 siklus dengan langkah-langkah penelitian tindakan kelas; perencanaan, pelaksanaan, pengamatan, dan refleksi. Penelitian dilakukan dengan menggunakan instrument berupa hasil catatan observasi,wawancara dan dokumentasi. Teknik analisis data yang digunakan dalam penelitian ini adalah analisis deskriptif kuantitatif. (suharsimi Arikunto, 2010) menyatakan bahwa analisis deskriptif digunakan untuk menggambarkan bahwa tindakan yang dilaksanakan dapat menimbulkan adanya perbaikan, peningkatan, dan perubahan ke arah yang lebih baik. Sedangkan analisis deskriptif kuantitatif untuk mengetahui persentase kemampuan mengenal huruf hijaiyah anak. adapun kerangkan pemikiran penelitian ini dijelaskan pada gambar 1 .

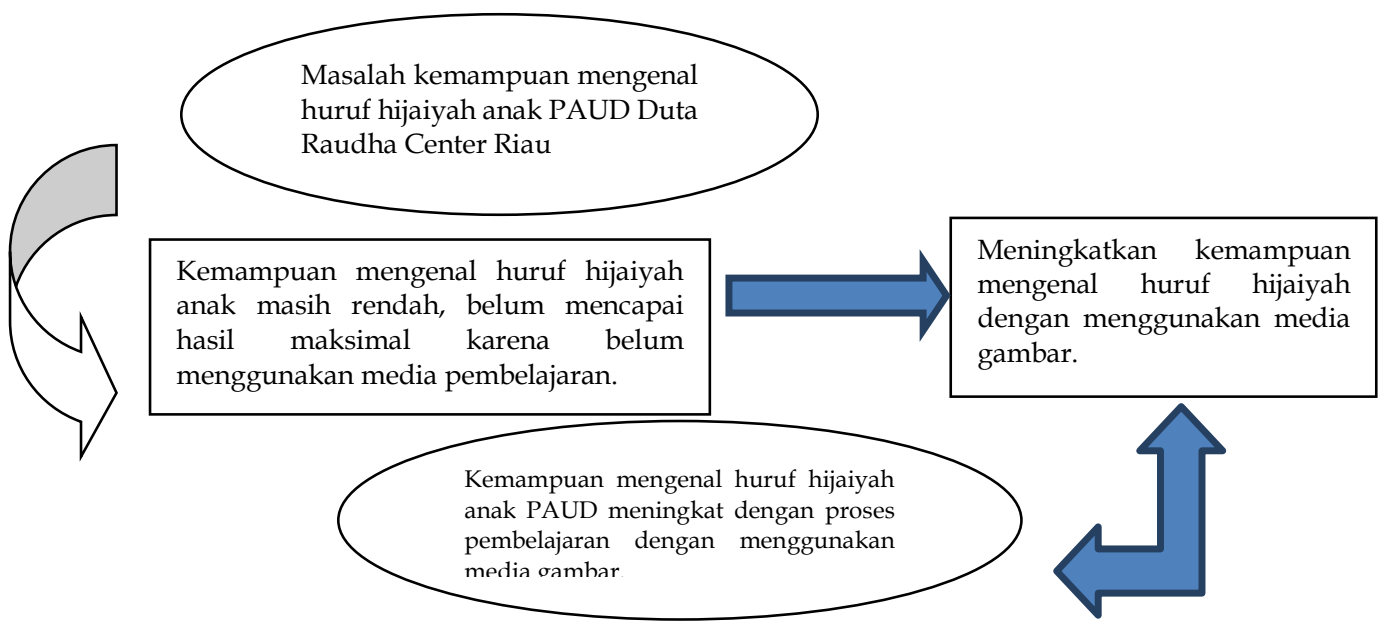

Gambar 1. Kerangka Berpikir penelitian

\section{HASIL DAN PEMBAHASAN}

Anak-anak di Kelas B mengalami permasalahan pada kurangnya kemampuan mengenal huruf hijaiyah. Berbagai identifikasi masalah telah dipaparkan menjadi penyebab rendahnya kemampuan mengenal huruf hijaiyah di kelas B PAUD Duta Raudha Center Riau Rumbai Pesisir. Untuk mengatasi permasalahan tersebut, telah dilaksanakan tindakan dengan menerapkan metode pembelajaran media gambar melalui kegiatan. Penerapan pembelajaran media gambar ini telah dilaksanakan dalam dua siklus yang masing-masing sebanyak 3 kali pertemuan. Metode pembelajaran media gambar ini dilakukan bertujuan untuk meningkatkan kemampuan mengenal huruf hijaiyah di kelas B PAUD Duta Raudha Center Riau Rumbai Pesisir. 
Pra-siklus dilaksanakan sebelum tindakan dilaksanakan yang disebut pra-tindakan. Observasi pratindakan dilakukan pada bulan Juni 2019. Pada tahap ini peneliti mengamati kemampuan mengenal huruf hijaiyah kelompok B. Hasil Observasi kemampuan mengenal huruf hijaiyah pratindakan anak dengan menggunakan instrumen lembar observasi hasilnya disajikan dalam tabel 1.

Tabel 1 : Kemampuan Mengenal Huruf Hijaiyah di Kelas B Pra Siklus

\begin{tabular}{|c|c|c|c|}
\hline Aspek & Indikator & Persentase & Kategori \\
\hline $\begin{array}{l}\text { Kemampuann } \\
\text { anak dalam }\end{array}$ & 1. Anak dapat mengetahui huruf-huruf hijaiyah & $93 \%$ & BSB \\
\hline $\begin{array}{l}\text { MengenalHuruf } \\
\text { Hijaiyah }\end{array}$ & $\begin{array}{l}\text { 2.Anak dapat menyebutkan huruf hijaiyah dari } \\
\text { awal sampai akhir }\end{array}$ & $92 \%$ & BSB \\
\hline $\begin{array}{l}\text { Kemampuan anak } \\
\text { dalam }\end{array}$ & $\begin{array}{l}\text { 3. Anak dapat menyebutkan huruf hijaiyah } \\
\text { sesuai dengan makhrojal hurufnya }\end{array}$ & $34 \%$ & MB \\
\hline $\begin{array}{l}\text { menyebutkan } \\
\text { huruf hijaiyah }\end{array}$ & $\begin{array}{l}\text { 4.Anak dapat menyebutkan huruf hijaiyah } \\
\text { secara lengkap dan benar }\end{array}$ & $89 \%$ & BSB \\
\hline \multirow{3}{*}{$\begin{array}{l}\text { Kemampuan anak } \\
\text { dalam memahami } \\
\text { media gambar }\end{array}$} & $\begin{array}{l}\text { 5.Anak dapat memahami hubungan antara } \\
\text { bunyi dan huruf }\end{array}$ & $32 \%$ & MB \\
\hline & $\begin{array}{l}\text { 6.Anak dapat membedakan huruf hijaiyah yang } \\
\text { hampir memiliki kesamaan. }\end{array}$ & $28 \%$ & MB \\
\hline & Indikator Keberhasilan & $80 \%$ & \\
\hline
\end{tabular}

Berdasarkan tabel di atas dapat diketahui bahwa terdapat 3 indikator dari mengenal huruf hijaiyah yang sudah memenuhi indikator keberhasilan yakni mencapai $\geq 80 \%$. Sedangkan pada indikator yang belum memenuhi indikator keberhasilan, peneliti melakukan diskusi dengan kolaborator untuk menentukan rencana kegiatan yang akan dilaksanakan pada siklus pertama. Adapun indikator penilaian mengenal huruf hijaiyah yang akan dinilai pada siklus I dan II adalah anak dapat menyebutkan huruf hijaiyah sesuai dengan makhrojal hurufnya, anak dapat memahami hubungan antara bunyi dan huruf, dan anak dapat membedakan huruf hijaiyah yang hampir memiliki

Untuk lebih jelasnya berikut grafik yang menunjukkan hasil observasi meningkatkan kemampuan mengenal huruf hijaiyah anak kelas B PAUD Duta Raudha Center Riau. Lebih jelasnya dapat dilihat pada gambar 2 .

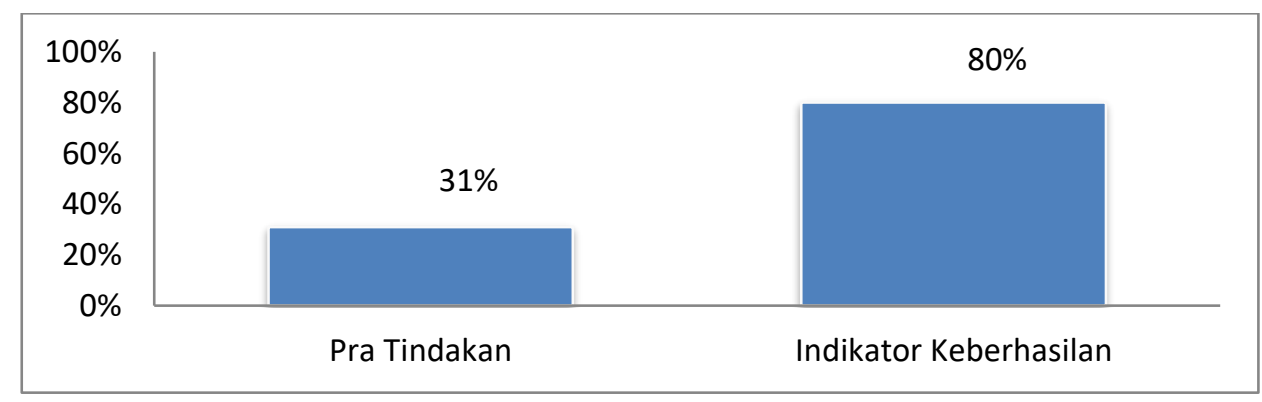

Gambar 2 : Grafik Kemampuan Mengenal Huruf Hijaiyah

Berdasarkan hasil observasi mengenal huruf hijaiyah anak pra tindakan, terdapat indikator yang belum berkembang. Hal ini terlihat dari hasil mengenal huruf hijaiyah anak pratindakan dengan rata-rata $31 \%$ dengan target pencapaian $76 \%$. Keadaan ini menjadikan landasan upaya mengembangkan kemampuan mengenal huruf hijaiyah melalui media gambar.

Peneliti melakukan diskusi untuk menentukan rencana kegiatan yang akan dilaksanakan pada siklus pertama. Setelah melakukan diskusi, maka langkah pertama yang akan dilaksanakan untuk memperbaiki kegiatan pembelajaran adalah memperbaiki metode 
pembelajaran bagi anak. Pada saat observasi, peneliti masih menggunakan metode bercakapcakap dan pemberian tugas yakni metode yang biasa diberikan oleh guru kelas, sehingga anak masih kurang bereksplorasi dengan pembelajarannya. Dan peneliti masih sedikit sekali memberikan pengarahan sebelum kegiatan sehingga anak masih bermain sesuka hati mereka.

Pada siklus 1, peneliti menggunakan bercakap-cakap sebagai upaya untuk meningkatkan kemampuan mengenal huruf hijaiyah pada anak. Kegiatan inti mengenal dan membaca huruf hijaiyah pada kegiatan akhir yakni dimana peneliti melakukan evaluasi terhadap kegiatan yang telah dilakukan, lalu dilanjutkan anak berdoa mau pulang dan salam. Sebelum masuk pada materi pembelajaran guru melakukan apersepsi sesuai dengan tema menyanyikan lagu "Pelangi-pelangi".

Setelah kegiatan awal, peneliti menjelaskan kegiatan yang akan dilaksanakan pada kegiatan inti. Pada tahapan ini, anak menyebutkan huruf hijaiyah di depan kelas dan mengisi huruf hijaiyah yang kosong sesuai dengan mukhrojal hurufnya. Kemudian guru mendemonstrasikan cara membaca huruf hijaiyah sesuai dengan mukhrojalnya, supaya anak paham dan mengerti. Selama proses kegiatan, peneliti mengamati anak yang sedang melakukan kegiatan. Setelah selesai kegiatan inti kegiatan akhir yakni dimana peneliti melakukan evaluasi terhadap kegiatan yang telah dilakukan pada hari ini, lalu dilanjutkan anak berdoa mau pulang dan salam. Sebagai ilustrasi pelaksanaan pembelajaran siklus 1, dapat dilihat pada gambar 3 dan 4 .

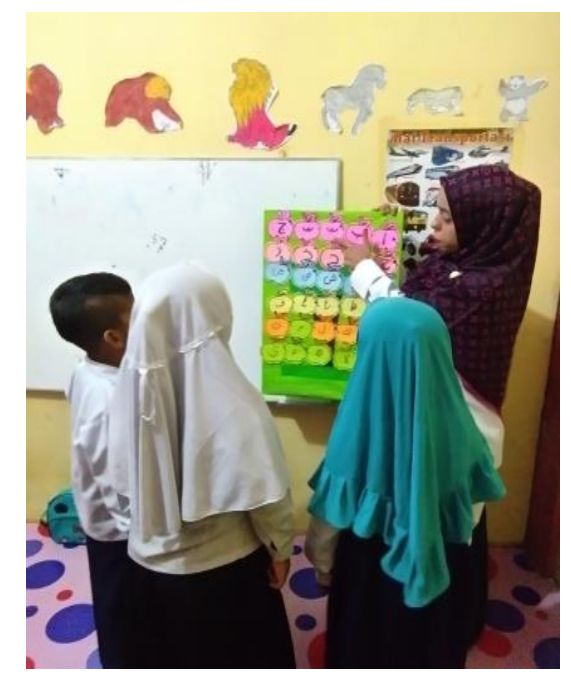

Gambar 3 : Menjelaskan Huruf HijaiyahPada Siklus I

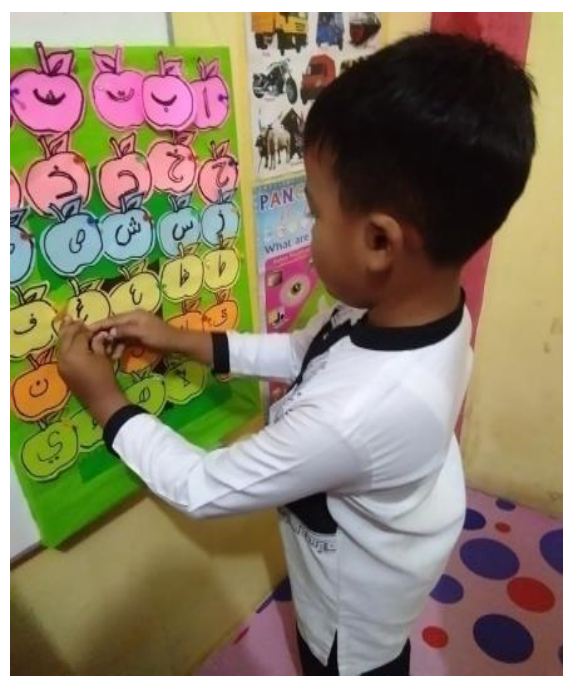

Gambar 4 : Mengenal dan Mengisi Huruf Hijaiyah yang Kosong Sesuai dengan Mukhrojalnya siklus I pertemuan 2

Hasil analisis data, kemampuan anak pada pertemuan 1 siklus 1 dipaparkan dalam tabel 2. Berdasarkan tabel 2 dapat dijelaskan bahwa kemampuan mengenal huruf hijaiyah anak di kelas B PAUD Duta Raudha Center Riau Rumbai Pesisir pada siklus 1 adalah sebagai berikut: Pada indikator anak dapat menyebutkan huruf hijaiyah sesuai dengan makhrojal hurufnya, persentase dengan kriteria Berkembang Sesuai Harapan (BSH) sebesar 57\%. Hal ini disebabkan masih terdapat anak yang belum bisa menyebutkan huruf hijaiyah sesuai mukhrojal hurufnya. Pada indikator anak dapat memahami hubungan antara bunyi dan huruf, persentase dengan kriteria Berkembang Sesuai Harapan (BSH) 53\%. Hal ini disebabkan masih terdapat anak yang belum bisa memahami hubungan antara bunyi dan huruf, sehingga anak tidak bisa membedakannya. Pada indikator Anak dapat membedakan huruf hijaiyah yang hampir memiliki kesamaan $(ب, \vec{\sqcup}, \dot{)}$ ), persentase dengan kriteria Berkembang Sesuai Harapan (BSH) sebesar 44\%. Hal ini disebabkan masih terdapat anak yang belum mengenal huruf hijaiyah. Seperti yang digambarkan pada grafik pada gambar 5. 
Tabel 2 : kemampuan Mengenal Huruf Hijaiyah Siklus I

\begin{tabular}{lcc}
\hline \multicolumn{1}{c}{ Indikator } & Persentase & Kategori \\
\hline 1. Anak dapat menyebutkan huruf hijaiyah sesuai dengan makhrojal & $57 \%$ & $\mathrm{BSH}$ \\
hurufnya & & $\mathrm{BSH}$ \\
2. Anak dapat memahami hubungan antara bunyi dan huruf & $53 \%$ & $\mathrm{BSH}$ \\
3. Anak dapat membedakan huruf hijaiyah yang hampir memiliki & $44 \%$ & \\
kesamaan. & & \\
\hline \multicolumn{2}{c}{ Rata-rata } & $\mathbf{8 0 \%}$ \\
\hline
\end{tabular}

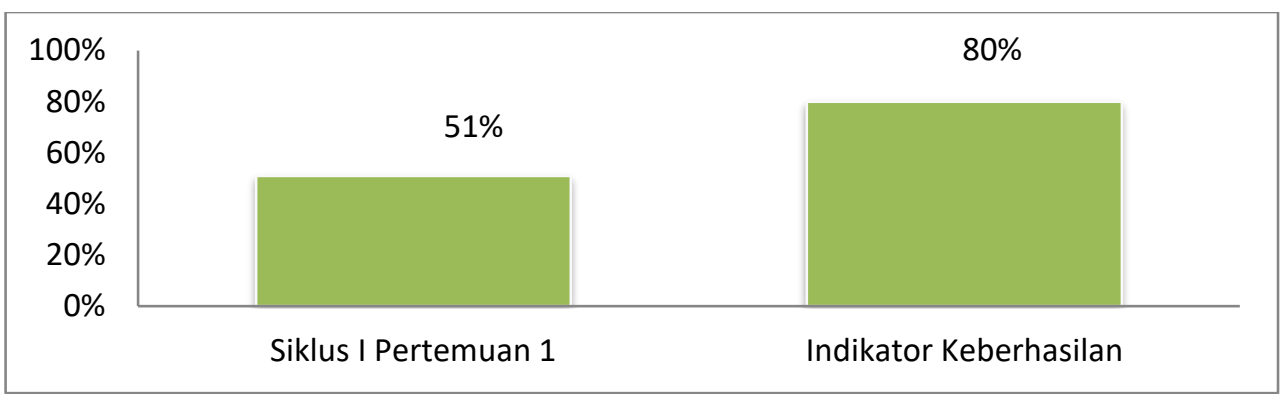

\section{Gambar 5 : Grafik Hasil Mengenal Huruf Hijaiyah Siklus 1}

Berdasarkan hasil pada siklus 1, indikator keberhasilan mencapai $80 \%$. Hasil refleksi menunjukkan terjadi peningkatan kemampuan anak dalam mengenal huruf hijaiyah sebanyak 55\%. Telah terjadi perubahan pada kemampuan anak pada siklus 1 .

Penelitian ini dilanjutkan dengan siklus 2 untuk meningkatkan kemampuan anak dalam mengenal huruf dengan media gambar. Pada tahapan ini, anak diberi waktu untuk mewarnai gambar lambang huruf hijaiyah. Gambar 6 merupakan gambar yang telah berhasil diwarnai oleh anak di PAUD Raudha Center Riau.

Pada siklus 2 indikator anak dapat menyebutkan huruf hijaiyah sesuai dengan mukhrojal hurufnya, persentase dengan kriteria Berkembang Sangat Baik (BSB) sebesar 98\%. Hal ini disebabkan anak sudah mengenal huruf hijaiyah sesuai dengan mukhrojal hurufnya tetapi masih sering lupa. Pada indikator anak dapat memahami hubungan antara bunyi dan huruf, persentase dengan kriteria Berkembang Sangat Baik (BSB) 90\%. Hal ini disebabkan anak sudah mengenal hubungan antara bunyi dan huruf tetapi masih sering lupa. Pada indikator Anak dapat membedakan huruf hijaiyah yang hampir memiliki kesamaan, persentase dengan kriteria Berkembang Sangat Baik (BSB) sebesar 88\%. Hal ini disebabkan anak sudah mengenal huruf hijaiyah namun masih sering lupa. Kemampuan anak dalam mengenal huruf hijaiyah pada siklus 2 dapat dilihat pada gambar 7 .

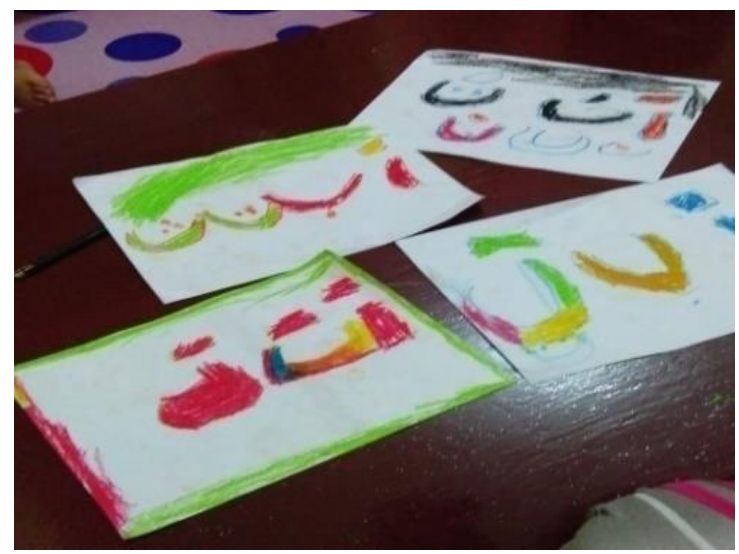

Gambar 6 : MembuatHuruf HjaiyahKemudian di Warnai Siklus II 


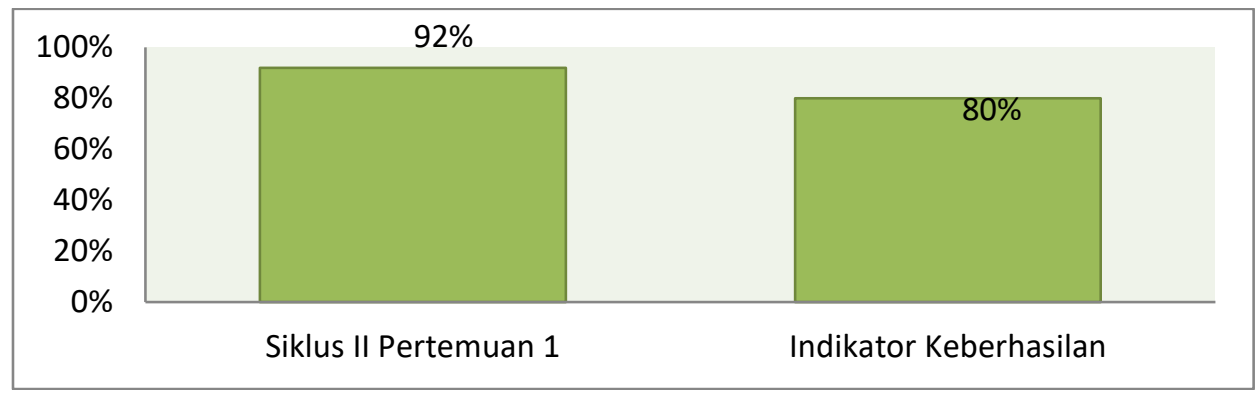

Gambar 7: Grafik Kemampuan Mengenal Huruf Hijaiyah Siklus II

Berdasarkan hasil pada siklus 1, indikator keberhasilan mencapai 80\%. Hasil refleksi menunjukkan terjadi peningkatan kemampuan anak dalam mengenal huruf hijaiyah sebanyak 55\%. Telah terjadi perubahan pada kemampuan anak pada siklus 1 . Penelitian ini dilaksanakan pada siklus 2 untuk meningkatkan kemampuan anak dalam mengenal huruf dengan media gambar yang akan diwarnai oleh anak di PAUD Raudha Center Riau. Terjadi peningkatan pada kemampuan anak $92 \%$ pada siklus 2 . Rekapitulasi kemampuan anak pada pra siklus, siklus 1, dan siklus 2 dapat dilihat pada gambar 8.

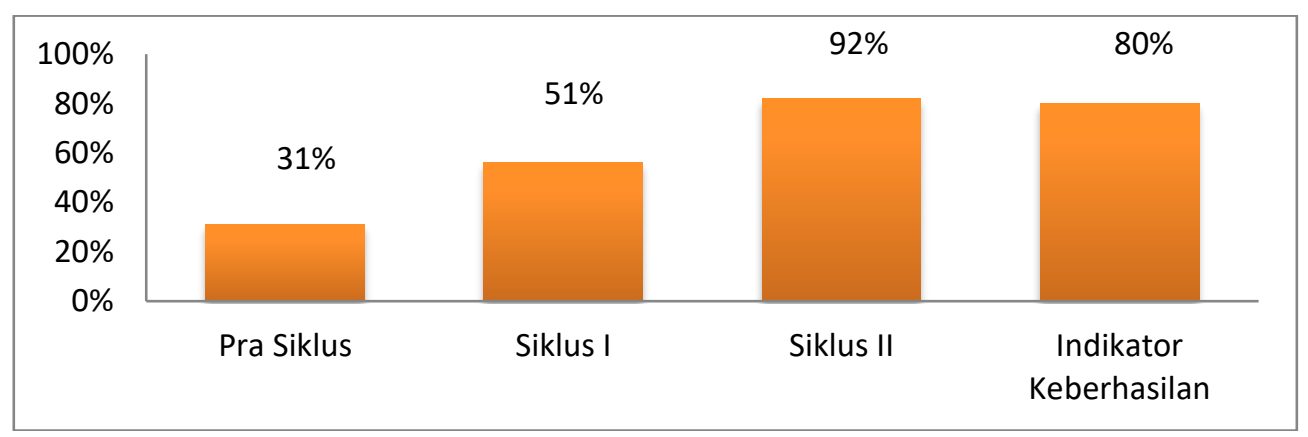

Gambar 8 : Grafik Rekapitulasi Kemampuan Mengenal Huruf Hijaiyah Pra Siklus, Siklus 1 dan Siklus 2

Keberhasilan tindakan yang terlihat dalam penelitian, telah menunjukkan adanya kesesuaian antara teori dengan hasil penelitian. Hal ini dapat terlihat melalui proses pembelajaran anak saat anak-anak mengerjakan kegiatan tersebut (Suhati et al., 2014). Mereka dapat mengingat huruf hijaiyah dengan cepat karena mereka menciptakan bentuk huruf hijaiyah tersebut, begitu juga dengan media yang lain. Anak-anak terlihat antusias dan penuh semangat saat mengerjakan menulis huruf hijaiyah tersebut.

Dari hasil penelitian pada pra siklus, kemampuan pengenalan anak $31 \%$ tergolong sangat rendah. Setelah dilakukan penelitian pada tindakan siklus pertama didapatkan peningkatan 51\%. Namun peningkatan tersebut masih dibawah keberhasilan yang diharapkan oleh peneliti sehingga peneliti melakukan siklus kedua. Dan setelah dilakukan penelitian siklus kedua didapatkan hasil yang sangat memuaskan dengan persentase $92 \%$. Aspek yang diukur dalam penelitian ini adalah kemampuan anak dalam mengenal huruf hijaiyah. Terdapat peningkatan kemampuan anak setelah dilaksanakan penelitian tindakan kelas dengan menggunakan gambar sebagai media pembelajaran.

Menurut Suhati \& Lestari (2015) Kemampuan adalah daya seseorang untuk melakukan sesuatu, sedangkan bahasa adalah penguasaan alat komunikasi baik secara lisan, tertulis, maupun menggunakan tanda-tanda dan isyarat. Bahasa merupakan alat komunikasi utama bagi anak untuk mengungkapkan berbagai keinginannya maupun kebutuhannya. Jadi kemampuan huruf adalah daya yang dimiliki anak dari sebuah proses belajar mengajar dalam hal kemampuan berkomunikasi. Menurut(Hasan Syahrizal et al., 2021), bahwa pengertian kemampuan mengenal huruf adalah kesanggupannya melakukan sesuatu dengan mengenali 
tanda-tanda/ciri-ciri dari tanda aksara dari tata tulis yang merupakan anggota abjad yang melambangkan bunyi bahasa. Pendapat (N. Sari et al., 2021)belajar huruf adalah komponen hakiki dari perkembangan baca tulis. Anak bisa membaca beberapa kata dan mengenal huruf cetak di lingkungan/environmental print sebelum mereka mengetahui abjad. Anak menyebut daftar huruf abjad, dalam belajar membaca tidak memiliki kesulitan dari pada anak yang tidak mengenal huruf. Nuraeni (n.d.) strategi pembelajaran sangat berpengaruh terhadap kemampuan anak dalam mengenal huruf yang merupakan hal penting bagi anak usia dini yang didengar dari lingkungannya baik huruf latin, huruf arab lainnya. Berbagai jenis huruf melatih anak untuk mengenal dan mengucapkan mesti harus diulang-ulang.

\section{SIMPULAN}

Kemampuan mengenal huruf hijaiyah anak kelas B PAUD Duta Raudha Center Riau dapat ditingkatkan dengan menerapkan pembelajaran melalui media gambar. Peningkatan tersebut dapat dilihat dari hasil pra tindakan yang awalnya berada pada kriteria mulai berkembang, meningkat pada siklus satu dan dua. Hal ini dapat dilihat dari adanya peningkatan kemampuan mengenal huruf hijaiyah setelah diterapkannya media gambar yakni pada siklus 1. Siklus II didapatkan perolehan persentase yang meningkat dari siklus sebelumnya dimana telah mencapai indikator keberhasilan yang telah ditetapkan sebelumnya. Hal ini menunjukkan bahwa media gambar sangat efektif digunakan dalam meningkatkan kemampuan anak usia dini.

\section{UCAPAN TERIMAKASIH}

Tim penulis mengucapkan terima kasih kepada Kepala Sekolah, Guru dan orang tua anak PAUD Duta Raudha Center Riau atas kesediannya membantu penelitian ini dan kepada redaksi Jurnal Obsesi: Jurnal Pendidikan Anak Usia Dini yang telah membantu dalam proses penerbitan naskah ini.

\section{DAFTAR PUSTAKA}

Aprinawati, I. (2017). Penggunaan Media Gambar Seri Untuk Meningkatkan Kemampuan Berbicara Anak Usia Dini. Jurnal Obsesi : Jurnal Pendidikan Anak Usia Dini, 1(1), 72. https:// doi.org/10.31004/obsesi.v1i1.33

Gusmita, D. E. (2018). Penggunaan Media Gambar Berwarna Dalam Meningkatkan Kemampuan Mengenal Warna di PAUD WITRI 1 Kota Bengkulu. Instititut Agama Islam Negeri Bengkulu.

Hasan Syahrizal, Sukarno, \& Abdul Muntholib. (2021). Kemampuan Mengenal Huruf Hijaiyah Melalui Media Kartu Bergambar. Mitra Ash-Shibyan: Jurnal Pendidikan Dan Konseling, 4(01), 59-70. https:// doi.org/10.46963/mash.v4i01.224

Inratyani, I. (2017). Meningkatkan Minat Baca Melalui Metode Bercerita Dengan Menggunakan Media Gambar Pada Anak Usia 5-6 Tahun. ... Seminar Nasional PG PAUD Untirta 2019, 97-104. http://semnaspgpaud.untirta.ac.id/index.php/semnas2017/article/view/13

Khotimah, S. H., Sunaryati, T., \& Suhartini, S. (2020). Penerapan Media Gambar Sebagai Upaya dalam Peningkatan Konsentrasi Belajar Anak Usia Dini. Jurnal Obsesi : Jurnal Pendidikan Anak Usia Dini, 5(1), 676. https:// doi.org/10.31004/obsesi.v5i1.683

Makulua, K. (2015). Strategi Guru Dalam Meningkatkankreativitas Anak Usia Taman Kanak$\begin{array}{llll}\text { Kanak. KENOSIS Jurnal Kajian } & \text { Teologi, 1(1), }\end{array}$ https:// doi.org/10.37196/kenosis.v1i1.23

Nazarah, H. (2017). Meningkatkan Pengenalan Kosakata Bahasa Arab melalui Pemanfaatan Media Gambar pada Anak Kelompok B Di RA Al-Jannah Jakarta. Jurnal Penelitian Dan Pengembangan Pendidikan Anak Usia Dini, 4(2), 113. https://doi.org/10.30870/jpppaud.v4i2.4651 
DOI: $10.31004 /$ obsesi.v6i3.1772

Nuraeni, N. (2014). Strategi Pembelajaran Untuk Anak Usia Dini. Prisma Sains: Jurnal Pengkajian Ilmu Dan Pembelajaran Matematika Dan IPA IKIP Mataram, 2(2), 143. https://doi.org/10.33394/j-ps.v2i2.1069

Purwani, A., Fridani, L., \& Fahrurrozi, F. (2019). Pengembangan Media Grafis untuk Meningkatkan Siaga Bencana Banjir. Jurnal Obsesi : Jurnal Pendidikan Anak Usia Dini, 3(1), 55. https:// doi.org/10.31004/obsesi.v3i1.142

Rahiem, M. D. H., \& Widiastuti, F. (2020). Pembelajaran Mitigasi Bencana Alam Gempa Bumi untuk Anak Usia Dini melalui Buku Bacaan Bergambar. Jurnal Obsesi: Jurnal Pendidikan Anak Usia Dini, 5(1), 36. https:// doi.org/10.31004/obsesi.v5i1.519

Rini, R., Suyuti, S., \& Imran, I. (2014). Menerapkan Media Gambar Berwarna Untuk Meningkatkan Hasil Belajar Pada Mata Pelajaran IPS Siswa Kelas III Sekolah Dasar Kecil Toraranga. Jurnal Kreatif Online, 3(4). http://jurnal.untad.ac.id/jurnal/index.php/JKTO/article/view/3065/2138

Sa'diyah, S., \& Zuhdi, U. (2014). Pemanfaatan Media Gambar untuk Meningkatkan Hasil Belajar pada Tema Diri Sendiri Siswa Kelas II SD Islam Plus Al-Azhar Mojokerto. Jurnal Penelitian Pendidikan Guru Sekolah Dasar (JPGSD), 3(2), 1-10. https://doi.org/10.33578/jpfkip.v3i1.2108

Sari, N., Wahyuningsih, S., \& Palupi, W. (2021). Upaya Meningkatkan Kemampuan Mengenal Huruf Hijaiyah Melalui Media Papan Flanel. Kumara Cendekia, 9(2), 76-84.

Sari, R. (2017). Peningkatan Kemampuan Mengenal Bentuk Geometri Melalui Model Pembelajaran Kooperatif Make A Match Pada Anak Usia 4-5 Tahun. Prosiding Seminar Nasional PG PAUD Untirta 2019, 205-210.

Suharsimi Arikunto. (2010). Prosedur Penelitian Suatu Praktik. Disi Revisi VI, Vol.2(9), Hlm.172.

Suhati, C., R, M., \& Lestari, S. (2014). Peningkatan Kemampuan Mengenal Huruf Hijaiyah Dengan Media Gambar Pada Anak Usia 5-6 Tahun. Jurnal Pendidikan Dan Pembelajaran, 3(9), 1-14.

Suhati, C., R, M., \& Lestari, S. (2015). Peningkatan Kemampuan Mengenal Huruf Hijaiyah Dengan Media Gambar Pada Anak Usia 5-6 Tahun. Jurnal Pendidikan Dan Pembelajaran Khatulistiwa, 3(9).

Sumarni, S. (2019). Implementasi Braille Berbasis Media Card Huruf Hijaiyyah Dalam Meningkatkan Kemampuan Mengenal Huruf Pada Tunanetra Siswa Sekolah Luar Biasa Negeri 1 Makassar. Al-Maraji': Jurnal Pendidikan Bahasa Arab, 3(2), 17-34.

Unicef. (2017). Anak-Anak di Indonesia: Analisis Kemiskinan, Mobilitas, dan Kekurangan Multidimensi. Unicef. 